\title{
Pemanfaatan Sistem Informasi dan Teknologi Informasi Pengaruhnya Terhadap Kinerja Individual Karyawan
}

\author{
Hj. Lindawati dan Irma Salamah \\ Politeknik Negeri Sriwijaya \\ Email: lindawati9111@yahoo.co; irma.salamah@yahoo.com
}

\begin{abstract}
ABSTRAK
Penelitian ini bertujuan untuk menguji pengaruh variabel prediktor yaitu : kesesuaian tugas-teknologi, persepsi kemanfaatan, kompleksitas, kondisi yang memfasilitasi dan kecemasan berkomputer pemanfaatan sistem informasi dan teknologi informasi terhadap kinerja individual karyawan dan menguji pengaruh keahlian sebagai variabel moderating terhadap hubungan antara kecemasan berkomputer dengan kinerja individual karyawan. Penelitian ini dilakukan pada bulan oktober 2010 terhadap 144 responden yang tersebar pada 9 BPR di Palembang. Model analisis yang digunakan untuk pengujian dalam penelitian ini adalah Analisis Regresi (Regression Analysis). Sedangkan untuk menguji pengaruh keahlian sebagai variabel moderating terhadap hubungan antara kecemasan berkomputer dengan kinerja individual menggunakan Moderated Regression Analysis (MRA). Hasil penelitian menunjukkan bahwa, variabel kesesuaian tugas-teknologi mempunyai hubungan negatif dan berpengaruh signifikan terhadap kinerja individual, persepsi kemanfaatan dan kecemasan berkomputer mempunyai hubungan positif dan berpengaruh signifikan terhadap kinerja individual karyawan. Sedangkan, variabel kompleksitas dan kondisi yang memfasilitasi tidak berpengaruh signifikan terhadap kinerja individual karyawan. Hasil penelitian juga menunjukkan bahwa keahlian sebagai variabel moderating secara signifikan mempengaruhi hubungan antara kecemasan berkomputer dengan kinerja individual karyawan.
\end{abstract}

Kata kunci: Sistem informasi, persepsi kemanfaatan, kinerja individu.

\begin{abstract}
The aim of this study are, first to examine the influence of five predictor variables namely task-technology fit, perceived usefulness, complexity, facilitating conditions and anxiety computing on the performance of individual employees and second, to test the effect of expertise as a moderating variable to the performance of individual employees. The study was conducted in October 2010 toward 144 respondents, spread over nine rural banks in Palembang. The statistical tests employed in this research are regression analysis and moderated regression analysis (MRA). Results show that task-technology fit has a negative significant effect to the individual performance, meanwhile perception of usefulness and anxiety computing have a positive significant influence to the individual performance. However, the rest variables that is complexity of variables and facilitating condition have no significant effect to the individual performance. Expertise as a moderating variable has a significant effect in relation between anxiety computing and the individual performance.
\end{abstract}

Keywords: Information system, perceived usefulness, individual performance.

\section{PENDAHULUAN}

Sistem informasi dan teknologi informasi merupakan hal fundamental yang harus dimiliki untuk melakukan kegiatan operasional suatu organisasi atau perusahaan. Rahadi (2007) menyebutkan bahwa saat ini sistem informasi dan teknologi informasi sudah menjadi kebutuhan dasar bagi perusahaan terutama dalam segala aspek aktifitas perusahaan. Sistem informasi dan teknologi informasi pada saat ini merupakan bagian yang tidak terpisahkan bagi dunia bisnis. Sistem informasi dan teknologi informasi berperan sebagai alat bantu dalam pembuatan keputusan 
bisnis pada berbagai fungsi maupun peringkat manajerial, karena kemampuan sistem informasi dan teknologi informasi dalam mengurangi ketidakpastian.

Bodnar dan Hopwood dalam Rahadi (2007) menyebutkan ada tiga hal yang berkaitan dengan penerapan teknologi informasi berbasis komputer yaitu perangkat keras (hardware), perangkat lunak (software) dan pengguna (brainware). Ketiga elemen tersebut saling berinteraksi dan dihubungkan dengan suatu perangkat masukan keluaran (input-output media), yang sesuai dengan fungsinya masing-masing. Perangkat keras (hardware) adalah media yang digunakan untuk memproses informasi. Perangkat lunak (software) yaitu sistem dan aplikasi yang digunakan untuk memproses masukan (input) untuk menjadi informasi, sedangkan pengguna (brainware) merupakan hal yang terpenting karena fungsinya sebagai, pengembang hardware dan software, serta sebagai pelaksana (operator) masukan (input) dan sekaligus penerima keluaran (output) sebagai pengguna sistem (user). Pengguna sistem adalah manusia (man) yang secara psikologi memiliki suatu prilaku (behavior) tertentu yang melekat pada dirinya, sehingga aspek keprilakuan dalam konteks manusia sebagai pengguna (brainware) teknologi informasi menjadi penting sebagai faktor penentu pada setiap orang yang menjalankan teknologi informasi.

Selanjutnya De Lone; Morgan dalam Syam; dalam Rahadi (2007) menyatakan bahwa penggunaan sistem informasi dan teknologi informasi bagi suatu perusahaan ditentukan oleh banyak faktor, salah satu diantaranya adalah karakteristik pengguna sistem informasi dan teknologi informasi. Menurut Goodhue et.al dalam Hapsari (2004) definisi karakteristik suatu aset sumber daya manusia yang bernilai adalah suatu staf sistem informasi dan teknologi informasi yang secara konsisten dapat memberikan solusi masalah-masalah bisnis dan meningkatkan peluang bisnis melalui sistem informasi dan teknologi informasi. Sedangkan, menurut Lucas \& Spitler dalam Jin (2003), agar sistem informasi dan teknologi informasi dapat dimanfaatkan secara efektif untuk memberikan kontribusi terhadap kinerja, maka anggota dalam organisasi harus dapat menggunakan teknologi tersebut dengan baik.

Pesatnya perkembangan sistem informasi dan teknologi informasi menjadikannya senjata dalam bersaing (competitive weapon) yang wajib dimiliki oleh perusahaan dalam memenangkan persaingan. Penerapan sistem informasi dan teknologi informasi dapat dikatakan berhasil jika dapat meningkatkan kinerja karyawan, yang pada akhirnya mampu meningkatkan kinerja perusahaan. Dengan adanya penerapan sistem informasi dan teknologi informasi tersebut perusahaan perlu mempersiapkan sumber daya manusia (SDM). Hal ini dinyatakan juga dari penelitian sebelumnya, dimana penggunaan sistem informasi dan teknologi informasi dalam menyelesaikan tugas-tugas operasional perusahaan dapat dijelaskan dari elemen kemanusiaan yang berada di belakang pemanfaatan sistem informasi dan teknologi informasi (Igbaria dan Guimares 1999 dalam Susanti 2006).

Penerapan sistem informasi dan teknologi informasi juga berpengaruh pada industri perbankan, dimana penerapan sistem informasi dan teknologi informasi pada industri perbankan mempunyai dampak yang luar biasa mengingat industri perbankan merupakan salah satu industri yang paling tinggi tingkat ketergantungannya pada aktivitas-aktivitas pengumpulan, pemrosesan, analisa dan penyampaian laporan (informasi) yang diperlukan untuk memenuhi kebutuhan para nasabahnya Roger dalam Muthalib. Pada umumnya tujuan pemanfaatan sistem informasi dan teknologi informasi pada industri perbankan lebih menekankan pada tingkat pengurangan kesalahan dalam memproses transaksi yang selama ini dilakukan secara manual dan memberikan informasi laporan keuangan yang akurat dan tepat waktu yang dapat digunakan oleh manajemen untuk membuat keputusan.

Bank Perkreditan Rakyat (BPR) yang termasuk dalam industri perbankan, sudah mulai menerapkan sistem informasi dan teknologi informasi sebagai implikasi dari tekanan persaingan yang begitu tajam. BPR merupakan lembaga keuangan yang mempunyai fungsi dan peran yang strategis dalam mendorong pertumbuhan usaha mikro, kecil dan menengah (UMKM) serta sekaligus sebagai lembaga keuangan yang dapat melakukan pemberdayaan para pengusaha lokal sebagai bentuk nyata kegiatan ekonomi yang berbasis kerakyatan. BPR juga merupakan lembaga jasa keuangan mikro dengan lingkup usaha seperti simpanan, pinjaman dan jasa pembayaran dalam bentuk yang sederhana. BPR sebagai lembaga keuangan mikro dengan UMKM sebagai lahan strategisnya, terbukti cukup tangguh dalam menghadapi krisis moneter yang pernah terjadi di Indonesia beberapa waktu yang lalu jika dibandingkan dengan bank umum. Akan tetapi saat ini ada bank pesaing BPR seperti Danamon Simpan Pinjam maupun lembaga keuangan mikro lainnya seperti gerai Pegadaian telah merambah sampai ke pedesaan yang memiliki prosedur dan layanan penyaluran kredit yang hampir sama dengan BPR yaitu cepat dan sangat sederhana. 
Masalah seperti inilah yang dikhawatirkan dapat mengancam kelangsungan hidup BPR.

Dalam mengatasi masalah prosedur dan penyaluran kredit dengan bank pesaingnya, penting bagi BPR untuk melakukan pengembangan sistem informasi dan teknologi informasi dan memperbaiki kinerja individual karyawan untuk memiliki keunggulan kompetitif sehingga bisa bersaing dengan bank umum yang telah mengaplikasikan program dan sistem yang lebih canggih serta lembaga keuangan mikro lain yang juga telah berkembang begitu pesat, dimana BPR harus mempersenjatai diri dengan sistem informasi dan teknologi informasi yang memadai. Dari segi perilaku individual karyawan terlihat realitas bahwa banyak karyawan yang masih merasa canggung untuk melakukan pekerjaannya dengan komputer padahal hal itu wajib untuk dipahami karena berhubungan dengan kegiatan tugas operasionalisasi BPR sehari-hari. Disamping itu BPR pada umumnya belum mempunyai staf ahli internal yang berkompeten di bidang sistem informasi dan teknologi informasi dan tidak memiliki bagian yang secara khusus mengelola sistem informasi dan teknologi informasi. BPR lebih mengandalkan bantuan pihak luar (eksternal) untuk melaksanakan kegiatan yang terkait dengan penggunaan sistem informasi dan teknologi informasi yang berbasis komputer. Ketergantungan dari pihak eksternal akan berkurang jika ada staf BPR telah memiliki keahlian terhadap sistem informasi dan teknologi informasi berbasis komputer.

Dengan adanya permasalahan BPR yang telah diuraikan tersebut, khususnya terkait dengan kinerja karyawan yang kurang baik, maka diperlukan suatu penelitian terhadap Bank Perkreditan Rakyat (BPR) dengan mengidentifikasi variabel-variabel yang berpengaruh terhadap kinerja karyawan yang berupa variabel prediktor dan variabel moderating. Variabel-variabel prediktor yang relevan dengan permasalahan yang dihadapi adalah kesesuaian tugas-teknologi, persepsi kemanfaatan, kompleksitas sistem, kondisi yang memfasilitasi dan kecemasan berkomputer (computer anxiety) serta variabel moderatingnya adalah keahlian (Jin 2003). Variabel moderating diperlukan dalam penelitian ini mengingat permasalahan BPR adalah pada umumnya belum mempunyai staf ahli internal yang berkompeten di bidang sistem informasi dan teknologi informasi dan tidak memiliki bagian yang secara khusus mengelola sistem informasi dan teknologi informasi serta secara realitas masih banyak karyawan yang merasa canggung untuk melakukan pekerjaannya dengan komputer, padahal hal itu wajib untuk dipahami mengingat berhubungan dengan kegiatan tugas operasionalisasi BPR sehari-hari. Permasalahan karyawan terhadap pemakaian komputer ini terkait dengan variabel prediktor kecemasan berkomputer (computer anxiety). Dengan adanya permasalahan tersebut maka dilakukan juga penelitian variabel kecemasan berkomputer terhadap kinerja individual dengan keahlian sebagai variabel moderatingnya. Kemudian diharapkan pengaruh keahlian sebagai variabel moderating hubungan antara kecemasan berkomputer dengan kinerja individual memberikan suatu penurunan tingkat kecemasan berkomputer bagi karyawan. Sehingga dengan adanya keahlian maka diharapkan kecemasan berkomputer tersebut dapat dikurangi bahkan dapat diabaikan, dengan demikian kinerja individual karyawan dapat meningkat.

Dengan berbagai permasalahan yang ada di dalam BPR yang terkait dengan kinerja individual karyawan, maka penelitian yang akan dilakukan terhadap BPR menggunakan 2 (dua) model penelitian, yaitu model penelitian yang pertama untuk mengidentifikasi pengaruh variabel kesesuaian tugas-teknologi, persepsi kemanfaatan, kompleksitas sistem, kondisi yang memfasilitasi dan kecemasan berkomputer (computer anxiety) terhadap kinerja individual dan model penelitian yang kedua untuk mengidentifikasi pengaruh keahlian sebagai variabel moderating terhadap hubungan antara kecemasan berkomputer dengan kinerja individual.

\section{Kesesuaian Tugas-Teknologi (Task-Techno- $\log y$ Fit) dan Kinerja Individual}

Variabel kesesuaian tugas-teknologi merupakan korespondensi antara kebutuhan tugas, kemampuan individual dan fungsi-fungsi teknologi dalam sistem informasi dalam organisasi (Goodhue 1995 dalam Ellyana, Redy dan Hamzah 2009). Kebutuhan tugas harus sesuai dengan kemampuan individu yang didukung dengan fungsi-fungsi teknologi sistem informasi (Hamzah 2009). Ketiga hal yaitu berupa kebutuhan tugas, kemampuan individu dan fungsi-fungsi teknologi sistem informasi merupakan satu kesatuan. Apabila cuma ada salah satu, maka tiada berakibat pada ketidakoptimalan kinerja individu maupun teknologi sistem informasi tersebut. Dengan kata lain, harus ada kesesuaian antara ketiga hal tersebut. Goodhue (1995) mengajukan konstruk kecocokan tugas-teknologi untuk dijadikan dasar evaluasi pemakai dalam mengukur keberhasilan suatu sistem informasi. Keberhasilan tersebut akan ditunjukkan dengan meningkatnya kinerja khususnya kinerja individu dalam organisasi. Dalam perspektif kecocokan tugas-teknologi, 
teknologi dipandang sebagai suatu hal yang berhubungan langsung dengan penyelesaian tugas individu. Kecocokan tugas-teknologi dalam hal ini didefenisikan sejauh mana fungsi teknologi sesuai/ cocok dengan kebutuhan tugas dan kemampuan individual (Goodhue \& Thompson 1995).

\section{Persepsi Kemanfaatan (Perceived Usefulness) dan Kinerja Individual}

Persepsi merupakan penafsiran realibilitas masing-masing orang dalam memandang realitas dari sudut perspektif yang berbeda (Winardi 1991 dalam Achjari dan Widowati 2004). Wiratno (1998) menyatakan persepsi pada hakikatnya adalah proses kognitif yang dialami oleh setiap individu di dalam memahami informasi tentang lingkungannya, baik lewat penglihatan, pendengaran, penghayatan dan perasaan. Davis.F.D (1989); Adam. et.al (1992) dalam Rahadi (2007) mendefinisikan kemanfaatan (usefulness) sebagai suatu tingkatan dimana seseorang percaya bahwa penggunaan suatu subyek tertentu akan dapat meningkatkan prestasi kerja orang tersebut. Berdasarkan definisi tersebut dapat diartikan bahwa kemanfaatan dari penggunaan komputer dapat meningkatkan kinerja, prestasi kerja orang yang menggunakannya.

Menurut Thompson et.al., (1991) dalam Jin (2003) kemanfaatan teknologi informasi merupakan manfaat yang diharapkan oleh pengguna teknologi informasi dalam melaksanakan tugasnya. Pengukuran kemanfaatan tersebut berdasarkan frekuensi penggunaan dan diversitas/keragaman aplikasi yang dijalankan. Thompson (1991) dalam Jin (2003) menyebutkan bahwa individu akan menggunakan teknologi informasi jika mengetahui manfaat positif atas penggunaannya.

\section{Kompleksitas (Complexity) dan Kinerja Indi- vidual}

Kompleksitas merupakan tingkat dimana inovasi dipersepsikan sebagai sesuatu yang relatif sulit untuk diartikan dan digunakan. Variabel ini mengacu pada teknologi yang digunakan oleh suatu organisasi, dengan anggapan bahwa kompleksitas adalah relatif terhadap setiap organisasi dan tidak mutlak (Tornatzky \& Klein 1982 dalam Jin 2003). Seperti penelitian yang dilakukan Thomson et al. (1991) dalam Jin (2003) bahwa faktor kompleksitas diperoleh hubungan yang negatif dan signifikan terhadap pemanfaatan sistem informasi dan teknologi informasi. Selain penelitian di atas, Sigalotang, Pontoh dan Syahrir (2006) dalam penelitiannya terhadap bank di kota Makassar menyimpulkan bahwa faktor komplek- sitas berpengaruh dan signifikan terhadap pemanfaatan sistem informasi dan teknologi informasi.

Dalam hubungannya dengan kinerja, Irma (2012) dalam penelitiannya terhadap dosen menemukan bahwa semakin kompleks teknologi informasi yang digunakan kinerja dosen akan menurun.

\section{Kondisi yang Memfasilitasi (Facilitating Condition) dan Kinerja Individual}

Dalam konteks pemanfaatan sistem informasi dan teknologi informasi, kondisi yang memfasilitasi dapat dimasukkan sebagai salah satu faktor yang mempengaruhi pemanfaatan sistem informasi dan teknologi informasi. Penelitian yang dilakukan oleh Schultz dan Slevin (1975) dalam Sigalotang, Pontoh dan Syahrir (2006) membuktikan bahwa kondisi yang memfasilitasi pengguna sistem informasi dan teknologi informasi atau dukungan untuk pengguna sistem informasi dan teknologi informasi merupakan salah satu faktor yang mempengaruhi pemanfaatan sistem informasi dan teknologi informasi. Namun penelitian yang dilakukan oleh Thompson et.al.(1991) dalam Jin (2003) menemukan hubungan yang negatif dan lemah antara kondisi yang memfasilitasi dengan pemanfaatan sistem informasi dan teknologi informasi, demikian pula hasil penelitian oleh Jin (2003) menemukan hubungan yang negatif dan lemah antara kedua variabel tersebut. Hasil penelitian Sigalotang, Pontoh dan Syahrir (2006) terhadap bank di kota Makassar menunjukkan bahwa faktor kondisi yang memfasilitasi berpengaruh positif dan signifikan terhadap sistem informasi dan teknologi informasi. Sedangkan Irma (2012) menemukan bahwa kondisi yang memfasilitasi akan meningkatkan kinerja individual.

\section{Kecemasan Berkomputer (Computer Anxiety) dan Kinerja Individual}

Kecemasan didefinisikan sebagai perasaan yang kuat berupa ketakutan (fear) dan keprihatinan yang tidak berhubungan dengan situasi khusus yang mengancam (Cherrington 1994 dalam Wibowo dan Hardiningsih 2003 dalam Ali dan Fadila 2008). Rosen dan Weil (1990), Maurer (1994) dalam Emmons (2003), telah menemukan adanya fenomena kecemasan berkomputer (computer anxiety). Kecemasan berkomputer dapat diartikan sebagai penolakan terhadap perubahan. Penolakan dapat berupa gejala atau sesuatu yang lain seperti ketakutan akan sesuatu yang tidak diketahui, ketakutan akan kegagalan, atau ketidakinginan untuk mengubah keadaan sekarang. 
Computer anxiety digambarkan sebagai suatu ketakutan terhadap komputer ketika menggunakannya atau kemungkinan yang menakutkan menggunakan komputer (Chua, Chan \& Wong 1999 dalam Sam 2005). Ini berbeda dari sikap negatif terhadap komputer yang memerlukan kepercayaan dan perasaan tentang komputer dibanding reaksi emosional terhadap menggunakan komputer (Heinssen, Glass \& Knight 1987 dalam Sam 2005). Computer anxiety dikarakteristik sebagai suatu respon yang efektif. Secara emosional takut akan hasil-hasil negatif potensial seperti merusakkan peralatan atau terlihat kebodohan. Dari suatu pengolahan informasi yang perspektif, perasaan negatif yang dihubungkan dengan kecemasan yang tinggi mengurangi sumber daya kinerja (Kanfer \& Heggested 1997 dalam Sam 2005). Jadi dengan demikian, computer anxiety yang tinggi akan menyebabkan kinerja yang lebih rendah jika dibandingkan dengan computer anxiety yang kecil atau tanpa computer anxiety.

Di Indonesia, Indriantoro (2000) saat meneliti dosen fakultas ekonomi pada perguruan tinggi swasta di Daerah Istimewa Yogyakarta (DIY), menemukan bahwa terdapat pengaruh yang signifikan negatif antara computer anxiety terhadap keahlian. Penelitian yang berkaitan dengan kecemasan berkomputer terdapat juga dalam penelitian yang dilakukan oleh Sumiyana (2007) dalam Ali dan Fadila (2008) mengenai analisis komparasi antara model concern for information privacy dan model internet users' information privacy concern dimana mahasiswa jurusan akuntansi juga dijadikan sampel. Hasil penelitian tersebut menunjukkan bahwa kecemasan berkomputer mempengaruhi perhatian terhadap masalah penyajian informasi privasi personal dan bahwa kecemasan berkomputer tidak memediasi hubungan perhatian privasi informasi dengan keperilakuan.

Adapun instrumen yang digunakan para peneliti untuk mengumpulkan data computer anxiety pada umumnya berdasarkan Computer Anxiety Rating Scale (CARS) yang dikembangkan oleh Heinssen et.al. (Heinssen et.al. 1987 dalam Havelka). CARS didalam mengukur computer anxiety berasal dari rangkaian pertanyaanpertanyaan yang dirancang untuk mengukur pengertian perorangan terhadap komputer. Instrumen CARS terdiri dari 19 item pertanyaan.

\section{Keahlian}

Keahlian sering dikaitkan dengan pengetahuan (knowledge) dan kepandaian (skill). Karena seseorang akan dikatakan ahli bila didukung dengan pengetahuan dan kepandaian. Keahlian komputer diukur dengan Computer Self-Efficacy Scale (CSE) yang dikembangkan oleh Murphy et.al (Murphy et.al dalam Khorrami (2001)). Skala ini terdiri dari 32 item pertanyaan dengan tingkat reliability internal sebagaimana yang telah dinyatakan oleh Harrison \& Rainer (1992) dalam Khorrami (2001). Murphy scale dikembangkan untuk mengukur self-perception individual terkait dengan knowledge dan skill. 32 item scale terdiri atas 3 (tiga) level yang berbeda tentang computing skill, yaitu beginner level, advance level, dan level yang dihubungkan dengan mainframe computer.

Bandura (1986) dalam Kevin (2007) menyatakan self-efficacy merupakan penilaian tentang kemampuan orang mengorganisir dan melaksanakan tindakan yang diperlukan untuk mencapai jenis-jenis kinerja. Hal ini terkait bukan hanya dengan mempunyai sebuah skill tetapi dengan penilaian apa yang seseorang dapat lakukan dengan skill apapun yang dimiliki. Computer SelfEfficacy digambarkan sebagai persepsi individual untuk menggunakan komputer dalam penyelesaian tugas (Compeau \& Hinggin, 1995 dalam Kevin 2007). Dalam Kevin (2007), Computer Self-Efficacy ditemukan memiliki suatu korelasi negatif yang kuat dengan computer anxiety (Compeau \& Hinggin 1995; Martocchio 1994; Harrison \& Rainer 1992; Igbaria et.al.1994; Henderson et.al. 1995), dampak positif pada sejumlah pemakaian komputer (Igbaria \& Liveri 1995) dan niat menggunakan komputer (Compeau \& Higgins 1995; De Vries et.al. 1995). Computer Self-Efficacy juga secara positif dihubungkan dengan pengalaman komputer (Busch 1995, 1996; Ogletrel \& William 1990 dalam Kevin 2007).

Computer Self-Efficacy menunjukkan penilaian individu dan kemampuan mereka menggunakan komputer dalam situasi yang berbeda (Compeau \& Higgins 1995 dalam Kang 2006). Pada sejumlah studi sistem informasi, konstruk self-efficacy berhubungan dengan pemakaian komputer dan pengembangan skill (Compeau \& Higgins 1995; Thatcher \& Perrewe 2002 dalam Kang 2006). Peneliti-peneliti menemukan bahwa Computer Self-Efficacy mempengaruhi computer anxiety tentang bagaimana persepsi individual dalam menggunakan sistem informasi dan teknologi informasi (Harrison \& Rainer 1992 dalam Kang 2006). Serta ada beberapa pembuktian yang mendukung Computer Self-Efficacy dapat memoderasi hubungan antara sikap.

\section{Kinerja Individual}

Pengertian Kinerja dalam organisasi merupakan jawaban dari berhasil atau tidaknya tujuan 
organisasi yang telah ditetapkan. Para atasan atau manajer sering tidak memperhatikan, kecuali sudah amat buruk atau segala sesuatu jadi serba salah. Terlalu sering manajer tidak mengetahui betapa buruknya kinerja, sehingga perusahaan/ instansi menghadapi krisis yang serius. Menurut Cecilia (2006) kinerja individual mengacu pada prestasi kerja individu yang diatur berdasarkan standar atau kriteria yang telah ditetapkan oleh suatu organisasi. Kinerja individual yang tinggi dapat meningkatkan kinerja organisasi secara keseluruhan. Penelitian Goodhue dan Thompson (1995) menyatakan bahwa pencapaian kinerja individual berkaitan dengan pencapaian serangkaian tugas-tugas individu. Kinerja yang lebih tinggi mengandung arti terjadinya peningkatan efisiensi, efektivitas atau kualitas yang lebih tinggi dari penyelesaian serangkaian tugas yang dibebankan kepada individu dalam perusahaan atau organisasi.

Sumber daya manusia merupakan faktor yang mempunyai proporsi terbesar dalam menerapkan variasi dari kerja dibandingkan dengan strategi dan faktor-faktor lainnya (Hensen dan Wernerfelt 1989 dalam Achjari \& Widowati 2004). Disamping itu, Goodhue \& Thompson (1995) dalam Ellyana, Redy dan Hamzah (2009) juga mengemukakan bahwa agar suatu sistem informasi dan teknologi informasi dapat memberikan dampak yang positif terhadap kinerja individual maka teknologi tersebut harus dimanfaatkan dengan tepat dan harus mempunyai kecocokan dengan tugas yang didukungnya. Kinerja yang lebih baik akan tercapai jika individu dapat memenuhi kebutuhan individual dalam melaksanakan dan menyelesaikan tugas (Goodhue dan Thompson 1995 dalam Jurnali 2001).

Berdasarkan penjelasan di atas maka hipotesis penelitian dapat dirumuskan sebagai berikut:

$\mathrm{H}_{1}$ : Kesesuaian tugas-teknologi mempunyai hubungan positif dan berpengaruh signifikan terhadap kinerja individual.

$\mathrm{H}_{2}$ : Persepsi kemanfaatan mempunyai hubungan positif dan berpengaruh signifikan terhadap kinerja individual.

$\mathrm{H}_{3}$ : Kompleksitas mempunyai hubungan negatif dan berpengaruh signifikan terhadap kinerja individual.

$\mathrm{H}_{4}$ : Kondisi yang memfasilitasi mempunyai hubungan positif dan berpengaruh signifikan terhadap kinerja individual.

$\mathrm{H}_{5}$ : Kecemasan berkomputer mempunyai hubungan negatif dan berpengaruh signifikan terhadap kinerja individual.

$\mathrm{H}_{6}$ : Keahlian secara signifikan mempengaruhi hubungan antara kecemasan berkomputer dengan kinerja individual.

\section{METODE PENELITIAN}

Penelitian ini dilakukan di Bank Perkreditan Rakyat (BPR) di Palembang. Adapun BPR yang dijadikan obyek penelitian adalah BPR yang berkantor pusat di Palembang dan telah menerapkan sistem informasi dan teknologi informasi. Jumlah BPR yang diteliti adalah 9 BPR. Penelitian ini dilakukan terhadap semua populasi yaitu semua karyawan BPR yang terlibat secara langsung dalam penggunaan sistem informasi dan sistem informasi dan teknologi informasi.

\section{Tabel 1. Karakteristik responden}

\begin{tabular}{|c|c|c|}
\hline Keterangan & Jumlah & Persentase (\%) \\
\hline \multicolumn{3}{|l|}{ A. Umur: } \\
\hline 1. $21-30$ tahun & 97 & 67,4 \\
\hline 2. $31-40$ tahun & 37 & 25,7 \\
\hline 3. $41-50$ tahun & 9 & 6,2 \\
\hline 4. $>50$ tahun & 1 & 0,7 \\
\hline \multicolumn{3}{|l|}{ B. Jenis Kelamin: } \\
\hline 1. Pria & 59 & 41 \\
\hline 2. Wanita & 85 & 59 \\
\hline \multicolumn{3}{|l|}{ C. Pendidikan: } \\
\hline 1. SLTA & 27 & 18,7 \\
\hline 2. D3 & 32 & 22,2 \\
\hline 3. $\mathrm{S} 1$ & 78 & 54,2 \\
\hline 4. $\mathrm{S} 2$ & 7 & 4,9 \\
\hline \multicolumn{3}{|l|}{ D. Jabatan: } \\
\hline 1. Manager & 5 & 3,5 \\
\hline 5 Staf & 83 & 57,6 \\
\hline 6 Customer & 21 & 14,6 \\
\hline Sevice & 35 & 24,3 \\
\hline 7 Teller & - & - \\
\hline 8 Dan lain-lain & & \\
\hline \multicolumn{3}{|l|}{ E. Lama Kerja: } \\
\hline 1. $<1$ tahun & 37 & 25,7 \\
\hline 2. $1-5$ tahun & 92 & 63,9 \\
\hline 3. $5-10$ tahun & 8 & 5,5 \\
\hline 4. $>10$ tahun & 7 & 4,9 \\
\hline
\end{tabular}

Sumber: Data Primer yang Diolah, 2010

Data diperoleh dengan memberikan kuesioner kepada setiap karyawan para pengguna sistem informasi dan teknologi informasi di BPR. Data yang natinya diolah adalah jawaban responden terhadap kuesioner yang telah diberikan. Data kemudian dianalisis secara deskriptif dan inferensial. Untuk mengukur variabel prediktor, variabel dependen dan variabel moderating digunakan 5 poin skala Likert, yaitu: dari sikap responden yang sangat tidak setuju diwakili oleh poin (1) sampai sangat setuju yang diwakili poin (5).

Variabel yang digunakan dalam penelitian ini terdiri dari variabel prediktor, variabel dependen dan variabel moderating. Variabel prediktor (variabel independent) dalam penelitian ini adalah variabel kesesuaian tugas-teknologi, persepsi kemanfaatan, kompleksitas, kondisi yang memfasili- 
tasi dan kecemasan berkomputer. Variabel moderating dalam penelitian ini adalah keahlian. Variabel dependen (variabel terikat) dalam penelitian ini adalah kinerja individu para pengguna sistem informasi dan teknologi informasi.

Setelah data diperoleh, yang pertama dilakukan adalah melakukan analisis deskriptif. Analisis ini meliputi analisis karakteristik responden yang memberikan gambaran mengenai demografi responden penelitian (umur, jenis kelamin, jabatan, pengalaman kerja, pendidikan) dan deskripsi mengenai variabel-variabel penelitian (variabel prediktor, variabel dependen dan variabel moderating). Analisis ini untuk mengetahui nilai minimum, maksimum, rata-rata dan standar deviasi dari variabel-variabel penelitian. Setelah tahap ini selanjutnya dilakukan analisis inferensial untuk membuktikan hubungan antara variabel penelitian dan menarik kesimpulan mengenai jawaban responden yang diselidiki.

Model analisis data yang digunakan untuk menguji pengaruh variabel prediktor pada model penelitian pertama adalah metode analisis regresi (regression analysis), dengan terlebih dahulu melakukan uji asumsi klasik. Uji asumsi klasik digunakan untuk menguji apakah hasil analisis regresi yang dilakukan merupakan model analisis yang benar-benar bebas dari adanya gejala multikolinearitas, dan gejala heteroskedastisitas. Uji asumsi klasik terdiri dari: Uji Normalitas, Uji Multikolinearitas, Uji Heteroskedastisitas.

Model Umum persamaan Regresi yang digunakan sebagai berikut:

$\mathrm{Y}=\mathrm{a}+\mathrm{b}_{1} \mathrm{X}_{1}+\mathrm{b}_{2} \mathrm{X}_{2}+\mathrm{b}_{3} \mathrm{X}_{3}+\mathrm{b}_{4} \mathrm{X}_{4}+\mathrm{b}_{5} \mathrm{X}_{5}+\mathrm{e}$

Dimana:

$\mathrm{Y}=$ kinerja individual

$\mathrm{X}_{1}=$ kesuaian tugas-teknologi

$\mathrm{X}_{2}=$ persepsi kemanfaatan

$\mathrm{X}_{3}=$ kompleksitas

$\mathrm{X}_{4}=$ kondisi yang memfasilitasi

$\mathrm{X}_{5}=$ kecemasan berkomputer

$\mathrm{a}=$ konstanta

b $=$ slope regresi atau koefisien regresi setiap $\mathrm{X}$

$\mathrm{e}=$ error

Model analisis data yang digunakan untuk menguji pengaruh keahlian sebagai variabel moderating terhadap hubungan antara kecemasan berkomputer dengan kinerja individual pada model penelitian kedua adalah model Moderated Regression analysis (MRA). Model persamaan MRA untuk hipotesis 6 adalah dengan menggunakan kerangka kerja MRA yang terdiri dari 3 (tiga) persamaan regresi (Hair- Jr., Joseph F. et al. 1989

Tabel 2. Hasil Uji Validitas dan Realibilitas

\begin{tabular}{|c|c|c|c|c|c|}
\hline Variabel & Alpha & Keterangan & Item & CI-CT & Keterangan \\
\hline \multirow[t]{4}{*}{ Kesesuaian Tugas-Teknologi (X1) } & 0,706 & Reliabel & 1 & 0,567 & Valid \\
\hline & & & 2 & 0,517 & Valid \\
\hline & & & 3 & 0,474 & Valid \\
\hline & & & 4 & 0,409 & Valid \\
\hline \multirow[t]{3}{*}{ Persepsi Kemanfaatan (X2) } & 0,896 & Reliabel & 1 & 0,773 & Valid \\
\hline & & & 2 & 0,826 & Valid \\
\hline & & & 3 & 0,788 & Valid \\
\hline \multirow[t]{3}{*}{ Kompleksitas (X3) } & 0,287 & Reliabel & 1 & 0,366 & Valid \\
\hline & & & 2 & 0,337 & Valid \\
\hline & & & 3 & $-0,132$ & Tidak Valid \\
\hline \multirow[t]{4}{*}{ Kondisi yang Memfasilitasi (X4) } & 0,481 & Reliabel & 1 & 0,414 & Valid \\
\hline & & & 2 & 0,324 & Valid \\
\hline & & & 3 & 0,460 & Valid \\
\hline & & & 4 & 0,019 & Tidak Valid \\
\hline \multirow[t]{4}{*}{ Kecemasan Berkomputer (X5) } & 0,768 & Reliabel & 1 & 0,641 & Valid \\
\hline & & & 2 & 0,525 & Valid \\
\hline & & & 3 & 0,530 & Valid \\
\hline & & & 4 & 0,614 & Valid \\
\hline \multirow[t]{6}{*}{ Keahlian (Z) } & 0,675 & Reliabel & 1 & 0,445 & Valid \\
\hline & & & 2 & 0,449 & Valid \\
\hline & & & 3 & 0,545 & Valid \\
\hline & & & 4 & 0,461 & Valid \\
\hline & & & 5 & 0,119 & Tidak Valid \\
\hline & & & 6 & 0,368 & Valid \\
\hline \multirow[t]{3}{*}{ Kinerja Individual (Y) } & 0,863 & Reliabel & 1 & 0,756 & Valid \\
\hline & & & 2 & 0,785 & Valid \\
\hline & & & 3 & 0,649 & Valid \\
\hline
\end{tabular}

Sumber: Data Primer yang Diolah, 2010 
dalam Dharmayanti (2006). Ketiga persamaan regresi tersebut dinyatakan sebagai berikut:

$\mathrm{Y}=\mathrm{a}+\mathrm{b}_{1} \mathrm{X}_{5}+\mathrm{e}$

$\mathrm{Y}=\mathrm{a}+\mathrm{b}_{1} \mathrm{X}_{5}+\mathrm{b}_{2} \mathrm{Z}+\mathrm{e}$

$\mathrm{Y}=\mathrm{a}+\mathrm{b}_{1} \mathrm{X}_{5}+\mathrm{b}_{2} \mathrm{Z}+\mathrm{b}_{3}\left(\mathrm{X}_{5} \mathrm{Z}\right)+\mathrm{e}$

Dimana:

$\mathrm{Y}=$ kinerja individual

$\mathrm{X}_{5}=$ kecemasan berkomputer

$\mathrm{Z}$ = keahlian

$\mathrm{X}_{5} \mathrm{Z}=$ interaksi kecemasan berkomputer dan keahlian

$\mathrm{a}=$ konstanta

$\mathrm{b}=$ slope regresi atau koefisien regresi setiap $\mathrm{X}$

$\mathrm{e}=$ error

\section{HASIL PENELITIAN DAN PEMBAHASAN}

\section{Hasil Uji Validitas dan Reliabilitas Data}

Ringkasan hasil uji validitas dan reabilitas dapat dilihat pada tabel 2. Hasil uji validitas menunjukkan bahwa dari 27 item pertanyaan pada kuesioner tersebut, hanya 24 item pertanyaan yang dinyatakan valid. Dimana dari 27 item pertanyaan tersebut terdapat 3 item pertanyaan yang dinyatakan tidak valid. Sedangkan untuk uji realibilitas menunjukkan bahwa kisaran cronbach alpha antara 0,287 dan 0,896, dimana kisaran angka ini lebih besar dari $\mathrm{r}$ tabel, maka secara uji realibilitas kuesioner tersebut adalah reliabel. Dengan demikian dapat dikatakan bahwa kuesioner yang berjumlah sebanyak 144 buah tersebut layak digunakan sebagai alat ukur dalam penelitian ini.

Di dalam pengujian model penelitian I (pertama), analisis data dilakukan dengan menggunakan analisis regresi (regression analysis). Akan tetapi sebelum melakukan analisis regresi terlebih dahulu dilakukan pengujian asumsi klasik. Hasil pengujian asumsi klasik menunjukkan bahwa data terdistribusi normal serta bebas dari adanya gejala multikolinearitas, dan heteroskedastisitas. Ringkasan hasil analisis regresi dapat dilihat pada tabel 3 .

Berdasarkan hasil analisis regresi pada tabel 3 dapat diketahui bahwa: Variabel kesesuaian tugas-teknologi, persepsi kemanfaatan dan kecemasan berkomputer yang memiliki pengaruh secara signifikan terhadap kinerja individual. Variabel kesesuaian tugas-teknologi memiliki hubungan yang negatif dan berpengaruh signifikan. Hubungan tersebut ditunjukkan dengan nilai $\mathrm{t}=-2,080$ dan signifikan dibawah 0,05. Berdasarkan hasil tersebut maka hipotesis 1 dapat diterima, meskipun memiliki hubungan yang negatif. Variabel persepsi kemanfaatan memiliki hubungan yang positif dan berpengaruh signifikan. Hubungan tersebut ditunjukkan dengan nilai $\mathrm{t}=$ 3,105 dan signifikan dibawah 0,05 yaitu 0,002 Berdasarkan hasil tersebut maka hipotesis 2 dapat diterima. Variabel kecemasan berkomputer memiliki hubungan yang positif dan berpengaruh signifikan. Hubungan tersebut ditunjukkan dengan nilai $\mathrm{t}=2,673$ dan signifikan dibawah 0,05 yaitu 0,008. Berdasarkan hasil tersebut maka hipotesis 5 dapat diterima. Variabel kompleksitas dan kondisi yang memfasilitasi tidak berpengaruh secara signifikan terhadap kinerja individual. Berdasarkan hasil tersebut maka hipotesis 3 dan hipotesis 4 ditolak.

Berdasarkan pernyataan yang ada, menunjukkan bahwa hipotesis 1, hipotesis 2 dan hipotesis 5 diterima. Artinya hipotesis tersebut menunjukkan bahwa variabel kesesuaian tugas-teknologi, persepsi kemanfaatan dan kecemasan berkomputer berpengaruh terhadap kinerja individual karyawan. Sebaliknya hipotesis 3 dan hipotesis 4 menunjukkan hasil hipotesis ditolak. Artinya bahwa pada variabel kompleksitas dan kondisi yang memfasilitasi tidak berpengaruh terhadap kinerja individual karyawan pada Bank Perkreditan Rakyat.

Di dalam pengujian model penelitian II (kedua) dilakukan analisis data dengan menggunakan Moderated Regression Analysis (MRA). Analisis ini digunakan untuk mengetahui pengaruh interaksi antara variabel kecemasan berkomputer dan keahlian sebagai variabel moderating terhadap kinerja individual karyawan. Akan tetapi sebelum melakukan MRA terlebih dahulu dilakukan pengujian asumsi klasik. Hasil pengujian asumsi klasik menunjukkan bahwa data terdistribusi normal serta bebas dari adanya gejala multikolinearitas, dan heteroskedastisitas. Ringkasan hasil analisis Moderated Regression Analysis $(M R A)$ dapat dilihat pada tabel 4.

Tabel 3. Hasil Analisis Regresi (Regression Analysis)

\begin{tabular}{cccc}
\hline No & Variabel & t & Sig. \\
\hline 1 & Kesuaian tugas-teknologi (X1) & -2.080 & 0.039 \\
2 & Persepsi Kemanfaatan (X2) & 3.105 & 0.002 \\
3 & Kompleksitas (X3) & -0.951 & 0.343 \\
4 & Kondisi yang Memfasilitasi (X4) & 1.307 & 0.193 \\
5 & Kecemasan Berkomputer (X5) & 2.673 & 0.008 \\
\hline
\end{tabular}


Tabel 4. Hasil Moderated Regression Analysis (MRA)

\begin{tabular}{crcclc}
\hline Hipotesis & \multicolumn{1}{c}{ Persamaan Regresi } & Nilai F & \multicolumn{1}{c}{$\mathbf{R}^{\mathbf{2}}$} & \multicolumn{1}{c}{ Hasil } & Keterangan \\
\hline H6 & $\mathrm{Y}=2,910+0,264 \mathrm{X} 5(0,006)$ & $7,839(0,006)$ & 0,052 & $\begin{array}{l}\text { X5 berpengaruh positif } \\
\text { terhadap Y }\end{array}$ & Diterima \\
& $\mathrm{Y}=1,353+0,225 \mathrm{X} 5+0,452 \mathrm{Z}(0,000)$ & $10,708(0,000)$ & 0,132 & $\begin{array}{l}\text { X5 dan Z berpengaruh } \\
\text { terhadap Y }\end{array}$ & Diterima \\
& $\begin{array}{l}\text { Y }=-4,238+1,688 \mathrm{X} 5+1,851 \mathrm{Z}- \\
0,366 \mathrm{X} 5 \mathrm{Z}(0,030)\end{array}$ & $8,944(0,000)$ & 0,161 & Z sebagai moderating & Diterima \\
\hline
\end{tabular}

Sumber: Data Primer yang Diolah, 2010

Tabel 5. Hasil Pengujian Hipotesis 1-6

\begin{tabular}{cclc}
\hline NO & Hipotesis & \multicolumn{1}{c}{ Keterangan } & Hasil \\
\hline 1 & Hipotesis 1 & $\begin{array}{l}\text { Kesesuaian tugas-teknologi berpengaruh positif dan signifikan terhadap kinerja } \\
\text { individual }\end{array}$ & Diterima \\
2 & Hipotesis 2 & $\begin{array}{l}\text { Persepsi kemanfaatan berpengaruh positif dan signifikan terhadap kinerja } \\
\text { individual }\end{array}$ & Diterima \\
3 & Hipotesis 3 & Kompleksitas berpengaruh negatif dan signifikan terhadap kinerja individual \\
4 & Hipotesis 4 & $\begin{array}{l}\text { Kondisi yang memfasillitasi berpengaruh positif dan signifikan terhadap kinerja } \\
\text { individual }\end{array}$ & $\begin{array}{c}\text { Ditolak } \\
\text { Ditolak }\end{array}$ \\
5 & Hipotesis 5 & $\begin{array}{l}\text { Kecemasan berkomputer berpengaruh negatif dan signifikan terhadap kinerja } \\
\text { individual }\end{array}$ & Diterima \\
6 & Hipotesis 6 & $\begin{array}{l}\text { Keahlian secara signifikan mempengaruhi hubungan antara kecemasan } \\
\text { berkomputer dengan kinerja individual }\end{array}$ & Diterima \\
\hline
\end{tabular}

Sumber: Data Primer yang Diolah, 2010

Dari tabel 4 untuk pengujian hipotesis 6, pada persamaan (2) dimana setelah persamaan (1) ditambah dengan variabel keahlian sebagai variabel independen, koefisien determinasinya berubah menjadi 0,132 yang berarti bahwa variabel keahlian mempengaruhi kinerja individual dengan variasi perubahannya sebesar $8 \%$. Pada persamaan (3), setelah ditambah interaksi kecemasan berkomputer dan keahlian pada persamaan (2) terjadi peningkatan koefisien determinasi menjadi $16,1 \%$ yang berarti bahwa keahlian secara bersama-sama dengan kecemasan berkomputer berpengaruh terhadap kinerja individual. Hasil pengujian hipotesis 6 ini dapat ditinjau dari uji signifikansi simultan (uji F) dan uji signifikansi individual (uji t). Untuk Uji F menghasilkan nilai F sebesar 8,944 dengan tingkat signifikansi 0,000 yang menunjukkan signifikansi lebih kecil dari 0,005. Maka dapat dikatakan bahwa kecemasan berkomputer, keahlian dan interaksi antara kecemasan berkomputer dan keahlian secara bersamasama berpengaruh terhadap kinerja individual. Sedangkan secara uji t, interaksi kecemasan berkomputer dan keahlian dengan tingkat signifikansi 0,030 dan $\mathrm{t}=-2,199$ menyebabkan kenaikan koefisien determinasi menjadi 0,161 atau $16,1 \%$, sehingga dapat dinyatakan bahwa variabel keahlian merupakan variabel moderating. Dengan demikian Hipotesis $6(\mathrm{H} 6)$ yang menyatakan keahlian secara signifikan mempengaruhi hubungan antara kecemasan berkomputer dengan kinerja individual diterima. Kemudian untuk menyimpulkan bahwa apakah variabel keahlian sebagai variabel pure moderating ataukah quasi moderating, perlu diperhatikan persamaan (1), (2), (3). Disini terlihat bahwa ketiga persamaan tersebut berbeda, dengan $\mathrm{b} 2 \neq 0$ dan $\mathrm{b} 3 \neq 0$. Berdasarkan hasil ini dapat disimpulkan bahwa variabel keahlian merupakan variabel quasi moderating. Dimana keahlian selain sebagai variabel pemoderasi pengaruh kecemasan berkomputer terhadap kinerja individual, variabel ini juga dapat bertindak sebagai variabel prediktor. Ringkasan hasil hipotesis terlihat pada tabel 5 .

Hipotesis pertama (H1) dalam penelitian ini menyatakan bahwa kesesuaian tugas-teknologi mempunyai hubungan positif dan signifikan terhadap kinerja individual. Hipotesis ini diterima tetapi terdapat hubungan yang negatif dan signifikan antara kesesuaian-tugas teknologi terhadap kinerja individual. Kemungkinan yang menyebabkan adanya hubungan negatif ini adalah adanya ketidaksesuaian tugas-teknologi dimana didalam menyelesaikan pekerjaan, responden merasa terhambat dalam mengakses data untuk memperoleh data yang akurat dan tepat. Hal ini terdapat dalam item pertanyaan ke empat. Hasil pengujian ini tidak konsisten dengan penelitian Thomson et.al (2001) dalam Sigalotang, Pontoh, dan Syahrir (2006) yang menemukan hubungan yang positif dan signifikan antara kesesuaian-tugas teknologi dengan pemanfaatan sistem informasi dan teknologi informasi. Hasil pengujian ini juga tidak konsisten dengan penelitian Jin (2003) yang menemukan hasil yang negatif dan tidak signifikan antara kesesuaian tugas-teknologi. 
Hipotesis kedua (H2) dalam penelitian ini menyatakan bahwa persepsi kemanfaatan mempunyai hubungan positif dan berpengaruh signifikan terhadap kinerja individual. Hipotesis ini diterima secara signifikansi dengan signifikansi 0,002 lebih kecil dari 0,05 dan $\mathrm{t}=3,105$. Dari pengujian ini terlihat bahwa individual karyawan akan menggunakan sistem informasi dan teknologi informasi jika mengetahui manfaat positif atas pemanfaatan sistem informasi dan teknologi informasi. Hasil pengujian ini konsisten dengan Igbaria et.al. (1995) dalam Hermana dan Saputra (2005) dimana pelatihan komputer berpengaruh positif terhadap kemudahan dan manfaat sistem informasi dan teknologi informasi. Hasil ini juga konsisten dengan Chau (2001) dalam Rahadi (2007) dimana tingkat kemudahan dan manfaat berpengaruh positif terhadap manfaat Microsoft office.

Hipotesis ketiga (H3) dalam penelitian ini menyatakan bahwa kompleksitas mempunyai hubungan negatif dan berpengaruh signifikan. Hipotesis ini ditolak dengan signifikansi 0,343 lebih besar dari 0,05 dan $t=-0.951$. Hasil pengujian menunjukkan bahwa kompleksitas memiliki hubungan negatif dan sangat lemah atau tidak signifikan terhadap kinerja individual. Hasil ini konsisten dengan Jin (2003) yang menyatakan bahwa kompleksitas mempunyai hubungan yang negatif dan tidak signifikan terhadap pemanfaatan sistem informasi dan teknologi informasi. Hasil ini tidak konsisten dengan penelitian Thompson et.al (1991) dalam Sigalotang, Pontoh dan Syahrir (2006), dan Sigalotang, Pontoh dan Syahrir (2006) yang menyatakan bahwa kompleksitas mempunyai hubungan yang negatif dan signifikan terhadap pemanfaatan sistem informasi dan teknologi informasi. Semakin kompleks suatu sistem informasi dan teknologi informasi maka pemanfaatan sistem informasi dan teknologi informasi tersebut semakin rendah. Perbedaan antara hipotesis dengan hasil pengujian ini kemungkinan disebabkan oleh pengaruh dari kemampuan dan pengalaman responden. Dimana jika para karyawan memiliki kemampuan yang baik dan pengalaman yang memadai maka walaupun sistem informasi dan teknologi informasi tersebut kompleks, mereka tetap dapat memanfaatkan sistem informasi dan teknologi informasi untuk dapat menyelesaikan pekerjaan mereka. Hal ini ditunjukkan pada tabel karakteristik responden yang menyatakan bahwa sebesar 63,9\% responden memiliki lama kerja antara 1 tahun sampai 5 tahun, yang berarti merupakan suatu pengalaman kerja yang cukup tinggi bagi para karyawan BPR. Oleh karena itu kompleksitas tidak banyak berpengaruh terhadap kinerja individual karyawan BPR.

Hipotesis keempat (H4) dalam penelitian ini menyatakan bahwa kondisi yang memfasilitasi mempunyai hubungan yang positif dan berpengaruh signifikan terhadap kinerja individual. Hipotesis ini ditolak secara signifikan dengan nilai signifikansi 0,193 lebih besar dari 0,05 dan $\mathrm{t}=$ 1.307. Hasil ini konsisten dengan Sigalotang (2006) yang menyatakan bahwa kondisi yang memfasilitasi mempunyai hubungan positif dan tidak signifikan terhadap pemanfaatan sistem informasi dan teknologi informasi. Hasil ini berbeda dengan hasil penelitian oleh Thompson et al. (1991) dan Qadri (1997) dalam Jin (2003) yang menemukan bahwa terdapat hubungan negatif dan tidak signifikan antara kondisi yang memfasilitasi dengan pemanfaatan sistem informasi dan teknologi informasi. Dengan demikian hasil penelitian ini menunjukkan bahwa kondisi yang memfasilitasi mempunyai hubungan yang positif namun lemah. Kemungkinan munculnya hubungan yang lemah ini karena dalam pengukuran kondisi yang memfasilitasi adanya satu aspek panduan dalam menggunakan sistem informasi dan teknologi informasi. Walaupun setiap individu memiliki komputer di meja kerja masing-masing namun ada indikator bahwa jika mereka ingin memperoleh program baru atau menghadapi kesulitan sehubungan dengan pemanfaatan komputer, pihak bank tidak memfasilitasi akan hal tersebut. Dengan kata lain, dalam hal ini karyawan harus mencari solusinya sendiri.

Hipotesis kelima (H5) dalam penelitian ini menyatakan bahwa kecemasan berkomputer mempunyai hubungan negatif dan berpengaruh signifikan terhadap kinerja individual. Hipotesis ini diterima dengan signifikansi 0,008 di bawah 0,05 dan nilai $\mathrm{t}=2,673$. Hasil ini menunjukkan hubungan yang positif dan signifikan antara kecemasan berkomputer terhadap kinerja individual. Hasil pengujian ini tidak konsisten dengan (Rifa, Dandes dan Gundono 1999) yang menyatakan bahwa kecemasan berkomputer mempunyai hubungan yang negatif dan signifikan. Semakin cemas individual dalam berkomputer, maka kinerja individualnya akan semakin rendah. Kemungkinan munculnya hubungan yang positif dalam pengukuran kecemasan berkomputer secara individual, karena responden merasa belum mampu mengikuti pengembangan sistem informasi yang baru, perputaran karyawan serta adanya beberapa karyawan baru yang bekerja di BPR (hal ini ditunjukkan pada tabel 1 karakteristik responden, dimana masa kerja karyawan menduduki angka yang cukup tinggi untuk masa kerja kurang dari 1 tahun, yaitu sebesar 25,7\%). 
Beberapa hal inilah yang kemungkinan dapat menyebabkan kecemasan individual dalam menggunakan komputer.

Hipotesis keenam $(\mathrm{H} 6)$ dalam penelitian ini menyatakan bahwa keahlian mempengaruhi hubungan antara kecemasan berkomputer dengan kinerja individual. Hipotesis ini diterima dengan signifikansi sebesar 0,030 dan $\mathrm{t}=-2,199$ yang menunjukkan bahwa adanya hubungan negatif yang timbul sebagai akibat interaksi antara variabel kecemasan berkomputer dengan kinerja individual. Dengan timbulnya hubungan yang negatif ini, berarti bahwa dengan adanya keahlian maka kecemasan berkomputer dapat berkurang sehingga kinerja individual meningkat. Atau dengan kata lain, semakin berkurang kecemasan individual dalam berkomputer maka kinerja individual akan semakin tinggi.

\section{KESIMPULAN DAN SARAN}

\section{Kesimpulan}

Hasil penelitian ini menunjukkan bahwa variabel kesesuaian tugas-teknologi mempunyai hubungan negatif dan berpengaruh signifikan terhadap kinerja individual, variabel persepsi kemanfaatan dan kecemasan berkomputer mempunyai hubungan positif dan berpengaruh signifikan terhadap kinerja individual karyawan. Sedangkan variabel kompleksitas dan kondisi yang memfasilitasi tidak berpengaruh signifikan terhadap kinerja individual karyawan. Variabel keahlian sebagai variabel moderating secara signifikan mempengaruhi hubungan antara kecemasan berkomputer dengan kinerja individual.

\section{Saran}

Berdasarkan hasil pengujian yang telah dilakukan terhadap pengaruh variabel prediktor dan moderating pemanfaatan sistem informasi dan teknologi informasi terhadap kinerja individual karyawan BPR maka diharapkan adanya keterlibatan pihak manajerial dalam meningkatkan penerapan dibidang sistem informasi dan teknologi informasi untuk menunjang sistem informasi yang ada sehingga karyawan tidak merasa rumit dalam menyelesaikan tugas dan tanggung jawab individu yang bersangkutan. Hal ini mengingat sampai pada saat ini masih ada beberapa BPR yang digunakan sebagai obyek penelitian belum melakukan peningkatan penerapan sistem informasi dan teknologi informasi. Kemudian dari hasil pengujian pada penelitian ini diharapkan juga agar pihak BPR dapat terus meningkatkan pelatihan meskipun pelatihan telah sering dilakukan terhadap karyawan. Hal ini mengingat pada umumnya bank biasanya merekrut karyawan baru, rolling diantara karyawan serta adanya pengembangan sistem informasi yang baru bagi karyawan. Pelatihan bagi karyawan ini dapat bersifat orientasi (terutama untuk karyawan baru), pemberian modul-modul dalam bentuk hardcopy maupun softcopy yang dapat dipelajari sendiri oleh pengguna (karyawan) serta pendidikan khusus untuk menunjang pengetahuan akan sistem informasi dan teknologi informasi.

\section{DAFTAR PUSTAKA}

Achjari, D dan Widowati, E. (2004), Pengukuran Konsep Efektivitas Sistem Informasi: Penelitian Pendahuluan, Seminar Nasional Aplikasi Sistem informasi dan sistem informasi dan teknologi informasi, Yogyakarta, 19 Juni 2004.

Ali, S. dan Fadila (2008), Kecemasan Berkomputer (Computer Anxiety dan Karakteristik Tipe Kepribadian pada Mahasiswa Akuntansi. Simposium Nasional Akuntansi ke-11, Pontianak.

Cecilia Engko (2006), Pengaruh Kepuasan Kerja Terhadap Kinerja Individual Dengan Self Esteem Dan Self Efficacy Sebagai Variabel Intervening, Simposium Nasional Akuntansi 9 Padang.

Dharmayanti, Diah (2006), “Analisis Dampak Service Performance dan Kepuasan Sebagai Moderating Variable Terhadap Loyalitas Nasabah, Studi pada Nasabah Tabungan Bank Mandiri Cabang Surabaya”, Jurnal Manajemen Pemasaran, Vol. 1, No. 1, April 2006 : 35-43.

Ellyana, D.D., Redy, A. dan Hamzah, A. (2009), "Variabel Anteseden dan Konsekuensi Pemanfaatan Sistem Informasi (Studi Empiris pada Pemerintahan Kabupaten di Pulau Madura)", Jurnal Akuntansi dan Keuangan Indonesia, Volume 6, Nomor 1.

Emmons, B. A. (2003), Computer Anxiety, Communication Preferences and Personality Type in the North California Cooperative Extension Service, Unpublished Doctoral Dissertation, North California State University.

Goodhue, Dale L. and Thompson, Ronald, L. (1995), Task-Technology Fit and Individual Performance. MIS Quarterly, June, p. 6-15.

Hamzah, Ardi (2009), Evaluasi Kesesuaian Model Keprilakuan dalam Penggunaan Teknologi Sistem Informasi di Indonesia, Seminar Nasional Aplikasi Sistem informasi dan 
sistem informasi dan teknologi informasi (SNATI). Yogyakarta, 20 Juni 2009.

Hapsari, Mirma (2004), Pengaruh Sistem informasi dan sistem informasi dan teknologi informasi Berbasis Sumber Daya Terhadap Kinerja Perusahaan (Studi Empiris pada Bank Umum di Jawa Tengah, Tesis S-2. Universitas Diponegoro.

Havelka, B., Bensley, F., Broome, T. "A Study of Computer Anxiety Among Business Student". Mid-America Journal of Business, Vol. 19, No. 1.

Hermana, B dan Saputra, D. E. (2005), Analisis Model Persamaan Struktural untuk Proses Adopsi Sistem informasi dan sistem informasi dan teknologi informasi: Studi Pemanfaatan Microsoft Office oleh Karyawan Bank Perkreditan Rakyat di Kabupaten Indramayu. Seminar Nasional Soft Computing, Intelligent Systems and Information Technology.

Indriantoro, Nur (2000), "Pengaruh Computer Anxiety Terhadap Keahlian Dosen dalam Penggunaan Komputer". JAAI, Vol. 4, No. 2, Desember: 191-210.

Irma Salamah (2012), "Utilization of IT And The Effect on Individual Performance of Lecturers At State Polytechnic Sriwijaya", Journal of Economic, Business, \& Accountancy Ventura. Vol 15. No.1. April 2012.

Jin, Fung Tjhai (2003), "Analisis Faktor-Faktor yang Mempengaruhi Pemanfaatan Sistem informasi dan sistem informasi dan teknologi informasi dan Pengaruh Pemanfaatan Sistem informasi dan sistem informasi dan teknologi informasi terhadap Kinerja Akuntan Publik", Jurnal Bisnis dan Akuntansi, Vol. 5, No.1.

Jurnali, Teddy (2001), Analisis Pengaruh Faktor Kesesuaian Tugas-Teknologi dan Pemanfaatan Sistem informasi dan sistem informasi dan teknologi informasi Terhadap Kinerja Akuntan Publik, Simposium Nasional Akuntansi IV.

Kang, Y. Sik., and Lee, Heeseok (2006), Exploring The Role of Computer Self-Efficacy and Computer Anxiety in The Formulation of eSatisfaction.
Kevin, P., Pauli, Richard L., Gibson, Douglas, R. May (2007), "Anxiety and Avoidance: The Mediating Effects of Computer Self-Efficacy on Computer Anxiety and Intention to Use Computers". Review of Business Information Systems-First Quarter 2007, Volume 11, Number 1.

Khorrami, O.A. (2001), "Researching Computer Self-Efficacy". International Education Journal, Vol. 2, No. 4. Educational Research Conference 2001 Special Issue.

Muthalib, A. "Peran Sistem informasi dan sistem informasi dan teknologi informasi Dalam Perbankan Syariah: Studi Kasus Indonesia, JSI, MTI, Vol. 2, No. 2.

Rahadi, D. Rianto (2007), Peranan Sistem informasi dan sistem informasi dan teknologi informasi dalam Peningkatan Pelayanan di Sektor Publik. Seminar Nasional Teknologi 2007 (SNT 2007). Yogyakarta, 24 November 2007.

Rifa, Dandes dan M. Gundono (1999), "Pengaruh Faktor Demografi dan Personality Terhadap Keahlian dalam End-User Computing". Jurnal Riset Akuntansi Indonesia, Vol. 2, No.1, Januari: 20-36.

Sam, H.K., Othman A.E.A \& Nordin, Z.S. (2005), "Computer Self-Efficacy, Computer Anxiety and Attitudes toward The Internet". A Study Among Undergraduates in Unimas, Educational Technology \& Society, 8(4), 205-219.

Sigalotang, W.A., Pontoh, G.T., dan Syahrir. (2006), "Analisis Determinan Pemanfaatan Sistem informasi dan sistem informasi dan teknologi informasi dan Pengaruhnya Terhadap Kinerja Karyawan Bank di Kota Makasar", Jurnal Ekonomi Bisnis dan Akuntansi Ventura, Vol. 19, No. 3, Desember 2006.

Susanti, V.A. (2006), "Teknologi Tugas yang Fit dan Kinerja Individual". Jurnal Akuntansi dan Keuangan, Vol. 8, No. 1, Mei 2006: 24-34.

Wiratno, Dwi Haryono. (1998). "Pengukuran Tingkat Kepuasan Konsumen dengan Servqual Instrument, Wahana, Vol. 1, No.1. 